Food, Dairy and Home Economic Research

http:/www.journals.zu.edu.eg/journalDisplay.aspx?Journalld=1\&queryType=Master

\title{
A STUDY ON FOOD PATTERN INTAKE AND PREVALENCE RATE OF OVERWEIGHT AND OBESITY AMONG SCHOOL STUDENTS IN ZAGAZIG CITY
}

\author{
Ehdaa S. Abo El-Maaty ", Dalia A. Zaky, Hanan S. Towfik and A.A. El-Neshwy \\ Food Sci. Dept., Fac. Agric., Zagazig Univ., Egypt
}

Received: 25/06/2019; Accepted: 21/07/2019

\begin{abstract}
Study aims to assess the eating habits and its relationship with the prevalence of overweight and obesity in a sample of school students in Zagazig city, Egypt. A cross-sectional survey of 100 students (males and females) aged 12-17 years, who were chosen randomly during the school years 2018-2019. Students were asked to fill out a self-reported questionnaire that included questions on their eating, drinking, their weight, and height. Body mass index (BMI) was used to assess students' weight status. The results showed that $20.0 \%$ of the students were overweight, $14.0 \%$ were obese, while $(54.0 \%)$ were of normal weight $(30.0 \%$ of males compared to $24.0 \%$ of females), and $12.0 \%$ were underweight. Eating habits of the students showed that the majority (78\%) was eating breakfast irregularly (42.0\% of rural student compared to $36.0 \%$ urban student). Almost of students $(66.0 \%)$ reported eating three meals per day (36.0\% of rural student compared to $30.0 \%$ urban student). Obesity and overweight were prevalent among rural student; irregular and infrequent meals together with low vegetables intake and frequent snaking were the most common unhealthy eating habits of the participants. Also, obese and overweight students were significantly reported higher frequency of soft drinks, although there was an apparent negative association between soft drink and obesity, on recategorization, overweight-obese subjects consumed soft drinks at higher frequency $(60.3 \%$ on daily or several/day vs. $30.9 \%$ among the lean subjects), sweets and candy $(49.3 \%$ vs. $35.8 \%)$, cakes/ cookies/doughnut and alike foods ( $49.6 \%$ vs. $27.1 \%$ in the lean students) and potato chips/popcorn/and other packed foods ( $29.0 \%$ vs. $6.5 \%$ in the lean students).
\end{abstract}

Key words: Overweight, obesity body, mass index, rural, urban, eating habits.

\section{INTRODUCTION}

Healthy lifestyle habits, including healthy eating and physical activity can lower the risk of becoming obese and developing related diseases. Schools are regarded as an excellent setting to promote lifelong healthy behaviors through nutritional educational programs. Schools are considered the next most important influencer in childhood development after parents. Some of the reasons, schools are so important in promoting healthy lifestyle habits are reported by Pietsch (2009) and earlier by WHO (1998). All student and youth can be reached, 1-2 meals are consumed by students at school, role models of teachers, and student

\footnotetext{
*Corresponding author: Tel. : +201006615895

E-mail address: Ehdaa sami 142@gmail.com
}

attends school for about nine months of years. Furthermore, school-based interventions can improve eating behaviors of youth, it is therefore important that the school environment enable and reinforce healthful eating and health behaviors through behavioral-focused classroom instruction (Tawfik et al., 2015).

Prevalence of obesity has increased to alarming levels in the last few decades, which acts as an independent risk factor leading to the development of a number of non-communicable diseases such as diabetes, cardiovascular diseases and cancer. Consequently they resulted in increase in morbidity and mortality rates, as well as increase in healthcare expenditure. In particular, obesity among student and adolescents is 
becoming an epidemic due to various life style changes, both in the developed and developing nations (Bibiloni et al., 2013). As per World Health Organization (WHO) estimates, 41 million student under five years and more than 340 million student and adolescents in the age group of 5 to 19 years were having overweight or obesity in the year 2016 (WHO, 2018).

Pathogenesis of obesity in young is multifaceted, including hereditary, metabolic, environmental and socio-demographic factors (Raj and Kumar, 2010).

Obesity and overweight among student and adolescents have significant long term health consequences such as adult obesity, higher levels of cholesterol, higher and future incidence of coronary artery disease (Danasekaran and Ranganathan, 2019).

According to WHO (2004), 10\% of schoolaged student, between 5 and 17 years old, are estimated to be overweight or obese worldwide, and the situation is getting worse. In Egypt, according to Demographic and Health Survey (DHS) data in 2008, the rates of overweight and obesity are increasing with $11 \%$ of student aged 10-19 years old were overweight and the risk of obesity among those can reach up to $15 \%$ in males and 19\% in females (EI-Zanaty and Way, 2009). Childhood obesity has both immediate and long term effects on health and well-being; among the immediate effects, obese youth are more likely to carry the risk factors of cardiovascular disease and other chronic diseases and psychological problems such as poor selfesteem. Regarding the long term effects, obese youth are likely to be obese as adults and are therefore more at risk for adult chronic health problems (CDC, 2014; Pietsch, 2009)

Therefore, the aim of the current work was to examine eating habits and assess the prevalence of overweight and obesity among students in preparatory and secondary schools in some rural and urban areas of Zagazig city, Egypt.

\section{MATERIALS AND METHODS}

\section{Studied Groups}

The studied samples were from preparatory and secondary-school (boys and girls) aged between 12-17 years. They were selected from the schools in Zagazig city. The total randomly preparatory and secondary-school student samples were recorded 100 students, which divided as follows: 50 students from schools in rural areas sorted as 28 boys and 22 girls, and 50 students from urban areas sorted as 26 boys and 24 girls.

Data were collected during the academic years $2018-2019$.

\section{Tools of the Study}

\section{Social-economic survey}

It included the following aspects:

\section{Data related to the sample itself}

School, age, kind of school, place of living, fathers and mothers job and monthly income.

\section{Anthropometric measurements}

The anthropometric measurements included weight and length. Accurate measures are needed for an assessment of the nutritional status of a student relative to his or her past growth and to provide some indications of growth of the samples can be irregular and still consider normal due to differences in the rate of growth and maturation that can occur among student at the same chronological age the techniques suggested by WHO (1999).

\section{Body weight (Wt.)}

The student weight was obtained by using a kilogram scale ranging from 1-150 kilogram to the nearest $1.0 \mathrm{~kg}$ with minimum of the underclothing and without shoes.

\section{Length}

Height was taken to the nearest $0.5 \mathrm{~cm}$ using a centimeter ruler ranging from $0-200 \mathrm{~cm}$. The student stood on a flat floor without shoes; looking straight up. The head had been hold comfortably erect. The arms were hanging at the sides in natural manner. Shoulders perpendicular to the trunk. Straightened the legs and brings the footboard up.

\section{Body mass index (BMI)}

Using the data collected, Body Mass Index (BMI) was calculated $\left(\mathrm{kg} / \mathrm{Lm}^{2}\right)$ for each age and gender. Those in the 18.5-24.9 were considered as having normal BMI, student within $25-29.9$ 
were taken as overweight and those with 30 - 34.9 were taken as obese.

\section{Nutritional assessment}

The Nutritional assessment includes dietary intake and analyzing the dietary survey food preference pattern practices.

\section{Dietary intake}

The dietary intake included the following aspects: Twenty four- hour recall method and food frequency. A predestined dietary form was used to determine food intake by using 24- hour recall. It gave an idea about pattern of food consumption in rural and urban communities. Each student subject was asked to recall everything that he or she consumed, including food obtained away from home, quantities eaten. Then calculated the nutritive value of the intake using the Food Composition Tables for Egypt Nutrition Institute ARE (1996). These actual values were compared with the Dietary Reference Intake (DRI) of these age ranges (Nutrition, 2004). Interview was done with some of the scholar's mothers to confirm the dietary information and more knowledge about ingredients of the common dishes, to help in visualizing quantities. Boys and girls were provided with common measuring cups, spoons and plates. Protein, calories, iron and calcium of the dietary survey were analyses according to (DRI) for this age.

\section{Statistical Analysis}

Statistical analysis for the obtained data was carried out using SPSS version 20 computer program (Dominick and Derrick, 2001). All data were expressed by means and standard deviations of three replicates and were compared using one-way ANOVA and least significant difference (LSD) values with different letters within the same column differ significantly at $\mathrm{P}<0.01-0.05$.

\section{RESULTS AND DISCUSSION}

\section{Distribution of Student Characteristics in the Studied Samples}

Distribution of school student characteristics in rural and urban in Zagazig city is presented in Table 1. It can be seen that 28 of students were boys in rural area as ratio of $46 \%$. While the girls were 22 as $44 \%$. In urban area 26 of students were boys as $52 \%$ while the girls were 24 as $48 \%$. Results in Table 1 shows the distribution of students samples according to age in rural and urban. It can be seen that 21 of students aged between 12-14 years as a ratio of $42 \%, 29$ of students as ratio $58 \%$ aged between $15-17$ in rural area while in urban area were 20 of students under the age of 12- 14 years as a ratio of $40 \%, 30$ of students as a ratio of $60 \%$ aged between 15- 17 years.

\section{Distribution of Student Sample According to Fathers and Mothers Job in Rural and Urban in Zagazig City}

Results in Table 2 indicate the occupation of fathers of student. It can be seen that $34 \%$ are farmers, $46 \%$ employee, $10 \%$ free job, $6 \%$ business man and $4 \%$ lower in rural area. While in urban area there were no farmers, $64 \%$ employee, $24 \%$ free job, $10 \%$ business man and $2 \%$ lower. There were very high significant differences between father's job in rural and urban. Similar results were found by Nanda (2000). The same Table shows mothers job in rural. It can be seen that $26.0 \%$ were employee, $2.0 \%$ free job and $72.0 \%$ house wives. While in urban area there were $68 \%$ employee, $12.0 \%$ free job and $20.0 \%$ house wives. There were very high significant differences between fathers and mothers job in rural and urban. Similar results were found by Cesani et al. (2013) and Ezeama et al. (2015).

\section{Distribution of Student Sample According to Monthly Income of the Family in Rural and Urban in Zagazig City}

Table 3 shows that in rural area the majority of monthly income level of the family was low $(66.0 \%)$. The minority of monthly income of the family with high income level $(6.0 \%)$ was recorded in rural area families. While moderate income level were $(28.0 \%)$, in urban area. The majority of monthly income level of the family with high income level $(52.0 \%)$, the minority of monthly income of the family had low income level $(22.0 \%)$ while moderate income level were $(26.0 \%)$. There were very high significant differences between both areas. Similar results were reported by Shaikh et al. (2016). 
Abo El-Maaty, et al.

Table 1. Distribution of student characteristics in rural and urban in Zagazig city

\begin{tabular}{lcccccc}
\hline Item & \multicolumn{3}{c}{ Place of living } & \multicolumn{2}{c}{ Total } \\
\cline { 2 - 5 } & \multicolumn{2}{c}{ Rural } & \multicolumn{2}{c}{ Urban } & \\
\cline { 2 - 5 } & No. & $\mathbf{( \% )}$ & No. & $\mathbf{( \% )}$ & No. & $\mathbf{( \% )}$ \\
\hline Gender of student & 28 & 46 & 26 & 52 & 54 & 54 \\
-Male & 22 & 44 & 24 & 48 & 46 & 46 \\
- Female & 50 & 100 & 50 & 100 & 100 & 100 \\
Total & & & & & & \\
Age of student (years old) & 21 & 42 & 20 & 40 & 41 & 41 \\
$\mathbf{1 2 - 1 4}$ & 29 & 58 & 30 & 60 & 59 & 59 \\
$\mathbf{1 5 - 1 7}$ & 50 & 100 & 50 & 100 & 100 & 100 \\
Total & & & & & & \\
\hline
\end{tabular}

Table 2. Distribution of student sample according to father's and mother's job in rural and urban in Zagazig city

\begin{tabular}{lcccccc}
\hline Item & \multicolumn{3}{c}{ Place of living } & \multicolumn{2}{c}{ Total } \\
\cline { 2 - 5 } & \multicolumn{2}{c}{ Rural } & \multicolumn{2}{c}{ Urban } & \\
\cline { 2 - 5 } & No. & $\mathbf{( \% )}$ & No. & $\mathbf{( \% )}$ & No. & $\mathbf{( \% )}$ \\
\hline Father's job & 17 & 34 & 0 & 0 & 17 & 17 \\
- Farmer & 23 & 46 & 32 & 64 & 55 & 55 \\
- Employee & 5 & 10 & 12 & 24 & 17 & 17 \\
- Free job & 3 & 6 & 5 & 10 & 8 & 8 \\
- Business man & 2 & 4 & 1 & 2 & 3 & 3 \\
- Lower & 50 & 100 & 50 & 100 & 100 & 100 \\
Total & & & & & & \\
Mother's job & 13 & 26 & 34 & 68 & 47 & 37 \\
- Employee & 1 & 2 & 6 & 12 & 7 & 7 \\
- Free job & 36 & 72 & 10 & 20 & 46 & 46 \\
- House wife & 50 & 100 & 50 & 100 & 100 & 100 \\
Total & & & & & & \\
\hline
\end{tabular}


Table 3. Distribution of student sample according to monthly income of the family in rural and urban in Zagazig city

\begin{tabular}{|c|c|c|c|c|c|c|}
\hline \multirow[t]{3}{*}{ Item } & \multicolumn{4}{|c|}{ Place of living } & \multicolumn{2}{|c|}{ Total } \\
\hline & \multicolumn{2}{|c|}{ Rural } & \multicolumn{2}{|c|}{ Urban } & \multirow[b]{2}{*}{ No. } & \multirow[b]{2}{*}{$(\%)$} \\
\hline & No. & $(\%)$ & No. & $(\%)$ & & \\
\hline \multicolumn{7}{|l|}{ Monthly income of the family } \\
\hline$-1500-3000$ (LE) low & 33 & 66 & 11 & 22 & 44 & 44 \\
\hline - 3000-5000 (LE) moderate & 14 & 28 & 13 & 26 & 27 & 27 \\
\hline$\geq 5000$ (LE) high & 3 & 6 & 26 & 52 & 29 & 29 \\
\hline Total & 50 & 100 & 50 & 100 & 100 & 100 \\
\hline
\end{tabular}

\section{Distribution of Meals Consumption at Home, by Examined Students}

Eating breakfast and essential three meals at home in rural and urban in Zagazig city is shown in Table 4. There were significant differences between both areas. In rural area $84 \%$ of students eating breakfast at home, $4 \%$ sometimes, $10 \%$ rarely and $2 \%$ don't eating breakfast. While in urban area $72 \%$ of students eating breakfast, $14 \%$ sometimes, $8 \%$ rarely and $6 \%$ don't eating breakfast. In rural area $72 \%$ of students eating three meals, $24 \%$ sometimes, $4 \%$ rarely and $0 \%$ don't eating three meals. In urban area $60 \%$ of students eating three meals, $30 \%$ sometimes, $4 \%$ rarely and $6 \%$ don't eating three meals.

The high percentage of students with overweight or obesity may be a consequence of the fact that parents often repeat at home the meals that the student has already eaten at school (Table 4). Serving the breakfast before leaving home can by of advantage to the students. However, a second mid-day meal during the day may easily resulted in overfeeding, leading in consequence to excessive weight or obesity. Breakfast eaten at home prevents hypoglycemia and enhances resistance to cold, which in turn is important for prevention of infections. Adult age is a good time to easily shape behavior patterns and habits in a growing, also those related to diet and nutrition which become habitual and persist throughout the adult life (Friedrich and Rukojć, 2001).

\section{Distribution of Consumption of Supper Meals, by Examined Students}

Degree of preparing completely meals and student eating between the meals in rural and urban is shown in Table 5. There were high significant differences between both areas. There were in rural area $66 \%$ of students rarely preparing completely meals and $34 \%$ did not preparing completely meals. While in urban area $54 \%$ of students rarely preparing completely meals and $46 \%$ did not preparing completely meals. In rural area there were $80 \%$ of students eating between the meals, $10 \%$ sometimes, $6 \%$ rarely and $4 \%$ did not eat. While in urban area there were $56 \%$ of students eating between the meals, $32 \%$ sometimes, $4 \%$ rarely and $8 \%$ did not eat. Overweight and obesity were also correlated with between-meals eating, which was observed in nearly all the students (Table 4). The snacks eaten by the students usually comprised sweets, fruit, as well as sweet dairy products. The presence of sweets in the diet was reflected by a large portion of sucrose in the daily energy ration (Sadowska et al., 2010).

\section{Mean Bmi, Overweight and Obesity Among in the Studied Samples of Student's Rural and Urban Areas in Zagazig City}

From Table 6, the mean unnormal BMI among male in rural areas was 18.95 . According to that $(10.71 \%)$ were identified as overweight and (3.58\%) as obese. The mean BMI among female was 20.58 and $(26.92 \%)$ were identified 
Table 4. Distribution of student sample according to degree of eating breakfast and essential three meals at home in rural and urban in Zagazig city

\begin{tabular}{lcccc}
\hline Item & \multicolumn{4}{c}{ Place of living } \\
\cline { 2 - 5 } & \multicolumn{2}{c}{ Rural } & \multicolumn{2}{c}{ Urban } \\
\cline { 2 - 5 } & No. & $\mathbf{( \% )}$ & No. & $\mathbf{( \% )}$ \\
\hline -Rate of eating breakfast at home & 42 & 84 & 36 & 72 \\
- Yes & 2 & 4 & 7 & 14 \\
-Sometimes & 5 & 10 & 4 & 8 \\
-Rarely & 1 & 2 & 3 & 6 \\
- No & 50 & 100 & 50 & 100 \\
Total & & & & \\
Rate of eating essential three meals daily. & 36 & 72 & 30 & 60 \\
- Yes & 12 & 24 & 15 & 30 \\
-Sometimes & 2 & 4 & 2 & 4 \\
-Rarely & 0 & 0 & 3 & 6 \\
- No & 50 & 100 & 50 & 100 \\
Total & & & & \\
\hline
\end{tabular}

Table 5. Distribution of students according to degree of preparing completely meals and student eating between the meals in rural and urban in Zagazig city

\begin{tabular}{lcccc}
\hline Item & \multicolumn{4}{c}{ Place of living } \\
\cline { 2 - 5 } & \multicolumn{2}{c}{ Rural } & \multicolumn{2}{c}{ Urban } \\
\cline { 2 - 5 } & No. & $\mathbf{( \% )}$ & No. & $\mathbf{( \% )}$ \\
\hline Number of preparing completely meals & & & & \\
-Rarely & 33 & 66 & 27 & 54 \\
- No & 17 & 34 & 23 & 46 \\
Total & 50 & 100 & 50 & 100 \\
Number of students eating between the meals & & & & \\
- Yes & 40 & 80 & 28 & 56 \\
-Sometimes & 5 & 10 & 16 & 32 \\
-Rarely & 3 & 6 & 2 & 4 \\
- No & 2 & 4 & 4 & 8 \\
Total & 50 & 100 & 50 & 100 \\
\hline
\end{tabular}


Table 6. Mean BMI, overweight and obesity among students in rural and urban areas in Zagazig city

\begin{tabular}{lcccccccc}
\hline \multirow{2}{*}{} & \multicolumn{3}{c}{ Place of living } & \multicolumn{4}{c}{ Place of living } \\
\cline { 2 - 10 } & \multicolumn{3}{c}{ Male } & \multicolumn{3}{c}{ Female } \\
\cline { 2 - 10 } & \multicolumn{2}{c}{ Rural } & \multicolumn{2}{c}{ Urban } & \multicolumn{3}{c}{ Rural } & \multicolumn{2}{c}{ Urban } \\
\cline { 2 - 10 } & No. & $\mathbf{( \% )}$ & No. & $\mathbf{( \% )}$ & No. & $\mathbf{( \% )}$ & No. & $\mathbf{( \% )}$ \\
\hline $\mathbf{1 8 . 5 \leq}$ (un normal) & 3 & 10.71 & 3 & 11.54 & 3 & 13.63 & 3 & 12.50 \\
$\mathbf{1 8 . 5 - 2 4 . 9}$ (normal) & 21 & 75.00 & 13 & 50.00 & 14 & 63.64 & 6 & 25.00 \\
$\mathbf{2 5 - 2 9 . 9}$ (Over weight) & 3 & 10.71 & 7 & 26.92 & 3 & 13.63 & 8 & 33.33 \\
$\mathbf{3 0 ~ - 3 4 . 9}$ (Obese) & 1 & 3.58 & 3 & 11.54 & 2 & 9.10 & 7 & 29.17 \\
Total & 28 & 100 & 26 & 100 & 22 & 100 & 24 & 100 \\
\hline
\end{tabular}

as overweight and $11.54 \%$ were obese. While the mean BMI among boys in urban areas was 19.80 and it was also observed that the BMI was increasing with age. According to that $13.63 \%$ were identified as overweight and $9.10 \%$ as obese. It was seen that the mean BMI among girls was 22.20 and $33.33 \%$ were identified as overweight and $29.17 \%$ as obese. The mean BMI was found to be increasing with age these results are in agreement with Danasekaran and Ranganathan (2019), who found that $4.58 \%$ are obese in boys in rural areas and $(4.20 \%$ are obese in girls. While in urban areas $4.58 \%$ are obese in boys and $4.20 \%$ are obese in girls. Also, Genena and Salama (2017), found that at $28.9 \%$ of the students aged $18-26$ years were overweight, $11.8 \%$ were obese, while $55.8 \%$ were of normal weight $49.6 \%$ of males compared to $59.1 \%$ of females, and $3.5 \%$ were underweight.

\section{Dietary Intake and Food Frequency Consumption}

The number of servings/day of different foods included in the questionnaire revealed that: lean students consumed more servings of fruits, vegetables and dairy products including milk, while overweight-obese students consumed significantly higher servings of egg, potato (especially fried), carbonated soft drinks, sugary drinks, and sweet-candy per day.
Also, the food frequency of selected food groups during the last week revealed that: Obese and overweight students were frequently consumed meat and alternatives while less frequently consumed milk and milk products. On the other hand, lean students consumed more frequently fresh fruits and vegetables, however, $34.5 \%$ and $36.5 \%$ of the included students stated consumption of $\leq$ once per week for fresh fruits and vegetables (Table 7).

The stated frequency of certain obsegenic food items per week among the different groups in relation to BMI: showed that: obese and overweight students were significantly reported higher frequency of soft drinks, although there is an apparent negative association between soft drink and obesity, on re-categorization, overweightobese subjects consumed soft drinks at higher frequency $(60.3 \%$ on daily or several/ day $v s$. $30.9 \%$ among the lean subjects), sweets and candy (49.3\% vs. 35.8\%), cakes/cookies/ doughnut and alike foods $(49.6 \%$ vs. $27.1 \%$ in the lean students) and potato chips/popcorn/and other packed foods $(29.0 \%$ vs. $6.5 \%$ in the lean students) (Table 8 ).

\section{Content of Energy and Main Nutrition Components in Daily Food Rations of Examined Student in Zagazig City}

Daily food rations of the student were composed of the meals served at the school and 
Table 7. Basic food groups consumption as stated in frequency per week among included students distributed according to their Body Mass Index (BMI) classifications

Food group

Body mass index (BMI) classification

Obese and overweight None obese and overweight

$$
(\mathrm{N}=34) \text { No. }(\%) \quad(\mathrm{N}=66) \text { No. }(\%)
$$

- Meat and alternatives

$\leq$ Once /week

$5(14.71)$

$13(19.5)$

2-4 times/week

$14(41.17)$

27(40.7)

5-6 times/week

15 (44.12)

26(39.8)

- Milk, cheese and other dairy products

$\leq$ Once /week

$10(29.41)$

11(16.5)

2-4 times/week

$20(58.82)$

20(28.6)

5-6 times/week

4 (11.77)

$35(54.9)$

- Fruits:

$\leq$ Once /week

11(32.35)

22(34.0)

2-4 times/week

14(41.17)

16(24.6)

5-6 times/week

9 (26.48)

28(41.4)

- Vegetables:

$\leq$ Once/week

9(26.48)

25(38.3)

2-4 times/week

12(35.29)

$15(22.3)$

5-6 times/week

13(38.24)

26(39.4)

- Bread and other bakery products

$\leq$ Once /week

2-4 times/week

$8(23.53)$

9(13.3)

5-6 times/week

24(70.59)

53(80.7)

- Rice and other cereals

$\leq$ Once /week

$8(11.5)$

2-4 times/week

12(18.0)

5-6 times/week

46(70.5)

- Cocked vegetables

$\leq$ Once /week

12(35.29)

27(40.2)

2-4 times/week

12(35.29)

21(31.5)

5-6 times/week

10(29.41)

18(28.3) 
Table 8. Last week stated frequency of selected obesogenic food consumption distributed by the presence of overweight and obesity of included student

\begin{tabular}{|c|c|c|}
\hline \multirow[t]{2}{*}{ Food item frequency/week } & \multicolumn{2}{|c|}{ Obesity and overweight } \\
\hline & $\begin{array}{c}\text { Overweight and obese } \\
(\mathrm{N}=34) \text { N0. }(\%)\end{array}$ & $\begin{array}{c}\text { None overweight and obese } \\
(\mathrm{N}=66) \text { No. }(\%)\end{array}$ \\
\hline \multicolumn{3}{|l|}{ - Soft drinks (carbonated) } \\
\hline 1 -2 times/week & $6(19.5)$ & $25(37.4)$ \\
\hline 3-6 times/ week & $8(20.2)$ & $21(31.7)$ \\
\hline Once or more /day & $20(60.3)$ & $20(30.9)$ \\
\hline \multicolumn{3}{|l|}{ - Sweets/candy } \\
\hline 1 -2 times/week & $10(28.3)$ & $25(37.8)$ \\
\hline 3-6 times / week & $8(22.4)$ & $17(26.4)$ \\
\hline Once or more /day & $16(49.3)$ & $24(35.8)$ \\
\hline \multicolumn{3}{|c|}{ - Cakes/cookies/doughnut/biscuits } \\
\hline 1 -2 times /week & $9(26.1)$ & $25(37.4)$ \\
\hline 3-6 times / week & $8(24.3)$ & $23(35.5)$ \\
\hline Once or more /day & $17(49.6)$ & $18(27.1)$ \\
\hline \multicolumn{3}{|l|}{ - Chewing gum } \\
\hline 1 -2 times /week & $16(47.8)$ & $31(47.6)$ \\
\hline 3-6 times / week & $14(43.0)$ & $26(39.6)$ \\
\hline Once or more /day & $4(9.2)$ & $9(12.8)$ \\
\hline \multicolumn{3}{|l|}{ - Chocolate: } \\
\hline 1 -2 times /week & $16(53.6)$ & $37(55.8)$ \\
\hline 3-6 times / week & $13(37.9)$ & $26(39.8)$ \\
\hline Once or more /day & $7(8.4)$ & $3(8.3)$ \\
\hline \multicolumn{3}{|c|}{ - Potatoes chips /popcorn and packed foods } \\
\hline 1 -2 times /week & $11(33.1)$ & $26(39.6)$ \\
\hline 3-6 times / week & $13(37.9)$ & $36(53.9)$ \\
\hline Once or more /day & $10(29.0)$ & $4(6.5)$ \\
\hline \multicolumn{3}{|l|}{ - Pizza and alike foods: } \\
\hline 1 -2 times /week & $22(64.7)$ & $42(64.3)$ \\
\hline 3-6 times / week & $11(31.6)$ & $22(33.8)$ \\
\hline Once or more /day & $1(3.7)$ & $2(1.9)$ \\
\hline
\end{tabular}

$* \mathrm{P}<0.001$. 
those eaten at home. The mean total intake of most nutritional components in the diet considerably exceeded the standards (Table 9). The consumed amounts of total protein, animal proteins, copper, iron, vitamins A, B2, and B6 exceeded the recommended levels more than twice. Other B-group vitamins, vitamin C, phosphorus, magnesium, and sodium were supplied in a considerable surplus too in rural and urban areas (boys and girls).

The high level of protein supply is particularly dangerous. Despite their importance for the growth and development of the child, protein should be not consumed in such high levels. An excess may lead to acidification of the system and can burden the liver and kidneys and forced to excrete additional levels of nitrogen compounds (Weatherholtz et al., 1969).

Sodium is another dietary component supplied to the studied students in excess. Sodium increases water retention in the system and represents one of the factors underlying adult-age arterial hypertension. It should be stressed that dietary habits formed during childhood persist throughout the entire life (Gronowska-Senger, 2007). Hence, exposure to salt food in childhood may result in a preference of the taste of salt observed at a later age.

There were deficiencies in the diet of the studied pre-school student, daily supply of cholesterol, potassium, and calcium did not mean the recommended levels in rural and urban areas (boys and girls) (Table 9). Similar calcium deficiencies in the diets were found by Charzewska and Weker (2006).

Calcium deficiency during an intensive growth of the skeletal system may lead to rickets as well as to attaining a low final weight of the bone tissue, which in turn may resulted in early osteoporosis, osteopenia or an increased risk of fractures at an older age (Oltarzewski $\boldsymbol{e t}$ al., 2003). These disorders are also stimulated by an improper calcium-to-phosphorus ratio, observed in the studied diets, as well as the excessive intake of sodium (Table 9), since sodium enhances urinary excretion of calcium (Kleeman et al., 1964), especially at a low-calcium diet (Nordin and Policy, 1987).
Potassium deficiencies in the diet of the studied student probably results from a low consumption of whole grain cereal products and vegetables, which are among the food items usually disliked by students (Kolarzyk et al., 2000). Low level of potassium leads to acidification of the organism hampers the neuromuscular response and slows down cellular oxidation, (Ciborowska and Rudnicka, 2007) In terms of hypertension, low potassium can have a negative impact as an excess of sodium (WHO, 1999).

It should be noted that even small iron deficiencies lead to reduced physical fitness and disorders in the immunological system. In student, they also degrade the cognitive abilities and hamper learning processes due to impaired the metabolism of neurotransmitters and oxygen transport and accumulation in the central nervous system (Walter, 1994). Heavier and long-lasting iron deficiencies lead to hemoglobin synthesis disorders, anemia, and damage of mucous membranes, which in consequence impairs absorption of the other components of the diet (Leszczyńska et al., 2007; Sochacka-Tatara et al., 2008).

The deficiencies observed may have resulted from food preferences of the student as well as from an uncritical imposition of adult dietary habits upon the student.

Szczepaniak et al. (2002) observed that student like meat and cured meat products, especially ham, loin, and sausages, whereas those meat products that contain visible fat in places belong to those disliked. Also the student studied preferred lean meat products; however, these did not occur in the diet in sufficient amounts, which is reflected by iron deficiencies. It also became apparent during the study that the student generally disliked dairy products served in the schools. These were usually in the form of milk and milk drinks, as well as rennet cheeses. This corresponds to the results reported by Kozlowska-Wojciechowska and MakarewiczWujec (2005). Also Kolarzyk et al. (2008) observed that milk is the least preferable dairy product within the group students.

The results of the survey suggest that the student selected their preferable food items from those served in the school. Moreover, the parents prepared home meals according to the 
Zagazig J. Agric. Res., Vol. 46 No. (5) 2019

1513

Table 9. Dietary intake of energy and main nutrition components in daily food rations of examined students aged $12-17$ years old in rural an urban in Zagazig city

\begin{tabular}{|c|c|c|c|c|c|}
\hline \multirow[t]{2}{*}{ Item/day } & Rural girls & Urban girls & Rural boys & Urban boys & \multirow{2}{*}{$\begin{array}{c}\text { Norm } \\
\text { DRI }\end{array}$} \\
\hline & Mean \pm S.D & Mean \pm S.D & Mean \pm S.D & Mean \pm S.D & \\
\hline Water, L/day & $3.44 \pm 0.213$ & $2.48 \pm 0.195$ & $2.92 \pm 0.257$ & $2.82 \pm 0.171$ & 3 \\
\hline Calories, kcal & $1595.33 \pm 362.01$ & $1357.88 \pm 402.94$ & $1597.87 \pm 431.46$ & $1419.08 \pm 415.09$ & 1400 \\
\hline Protein a, $g$ & $32.88 \pm 20.37$ & $29.52 \pm 18.76$ & $31.06 \pm 25.44$ & $33.78 \pm 18.35$ & 35.0 \\
\hline Protein $\mathrm{p}, \mathrm{g}$ & $30.12 \pm 12.11$ & $22.57 \pm 9.72$ & $28.95 \pm 12.02$ & $22.12 \pm 8.51$ & 20.0 \\
\hline Total protein, $g$ & $63.01 \pm 22.38$ & $52.13 \pm 23.81$ & $60.01 \pm 30.62$ & $55.92 \pm 22.83$ & 55.0 \\
\hline Fat a, $g$ & $15.69 \pm 13.35$ & $26.22 \pm 16.23$ & $16.25 \pm 14.11$ & $24.31 \pm 18.15$ & 15.0 \\
\hline Fat $p, g$ & $29.93 \pm 15.56$ & $23.81 \pm 24.54$ & $29.66 \pm 13.66$ & $26.13 \pm 18.16$ & 35.0 \\
\hline Total fat & $45.63 \pm 14.87$ & $50.04 \pm 25.69$ & $45.89 \pm 19.61$ & $50.43 \pm 28.10$ & 50.0 \\
\hline Carb, g & $133.67 \pm 65.13$ & $173.54 \pm 68.68$ & $125.75 \pm 61.99$ & $186.51 \pm 54.05$ & 200 \\
\hline Fiber, g/day & $11.96 \pm 5.51$ & $6.4 \pm 7.81$ & $11.01 \pm 6.05$ & $5.82 \pm 5.87$ & 15 \\
\hline Ash, $g$ & $7.80 \pm 2.37$ & $7.85 \pm 3.96$ & $7.22 \pm 3.09$ & $6.73 \pm 3.06$ & - \\
\hline Calcium, mg & $1018.42 \pm 177.16$ & $1027.60 \pm 363.90$ & $1023.25 \pm 272.43$ & $1054.84 \pm 180.57$ & 1500 \\
\hline Phosphorus, mg & $916.51 \pm 242.33$ & $844.74 \pm 480.59$ & $937.03 \pm 374.51$ & $934.80 \pm 377.23$ & 1500 \\
\hline Iron a, mg & $5.46 \pm 3.58$ & $4.72 \pm 3.07$ & $5.63 \pm 5.23$ & $5.85 \pm 5.32$ & - \\
\hline Iron $\mathrm{p}, \mathrm{mg}$ & $13.65 \pm 7.13$ & $5.56 \pm 1.88$ & $12.75 \pm 8.57$ & $6.59 \pm 3.25$ & - \\
\hline Total iron & $19.10 \pm 7.44$ & $10.27 \pm 3.04$ & $18.38 \pm 10.00$ & $12.43 \pm 6.33$ & 20.00 \\
\hline Sodium, mg & $1853.56 \pm 619.00$ & $1606.40 \pm 777.10$ & $1825.73 \pm 415.18$ & $1800.10 \pm 797.54$ & 2000 \\
\hline Potassium, mg & $2335.93 \pm 623.57$ & 1557.67594 .43 & $2339.36 \pm 786.25$ & $1774.98 \pm 548.73$ & 2000 \\
\hline Zinc, mg & $46.57 \pm 1.94$ & $49.55 \pm 3.75$ & $42.54 \pm 2.70$ & $44.36 \pm 3.27$ & 50 \\
\hline Magnesium, mg & $985.43 \pm 75.44$ & $915.78 \pm 136.16$ & $988.85 \pm 110.14$ & $921.91 \pm 148.31$ & 1000 \\
\hline Vitamin A, $\mu \mathrm{g}$ & $625.23 \pm 637.73$ & $240.50 \pm 148.15$ & $205.84 \pm 154.07$ & $574.76 \pm 1667.20$ & 1000 \\
\hline Vitamin $\mathrm{C}, \mathrm{mg}$ & $50.74 \pm 203.74$ & $54.05 \pm 37.96$ & $48.76 \pm 66.45$ & $50.33 \pm 200.18$ & 50.0 \\
\hline Vitamin $\mathrm{D}, \mu \mathrm{g}$ & $8.41 \pm 4.92$ & $9.26 \pm 4.34$ & $6.91 \pm 3.71$ & $7.81 \pm 1.32$ & 10 \\
\hline Vitamin E, mg & $49.69 \pm 12.54$ & $52.26 \pm 8.72$ & $41.08 \pm 22.43$ & $50.70 \pm 7.56$ & 60 \\
\hline Vitamin B1, mg & $48.77 \pm .25$ & $42.63 \pm .19$ & $44.85 \pm .26$ & $40.60 \pm .20$ & 50 \\
\hline Vitamin B2, mg & $50.27 \pm .36$ & $48.94 \pm .38$ & $46.18 \pm .53$ & $44.02 \pm .61$ & 50 \\
\hline Niacin, mg & $89.85 \pm 3.72$ & $86.62 \pm 2.53$ & $79.62 \pm 3.42$ & $88.33 \pm 3.84$ & 100 \\
\hline Vitamin B6, mg & $41.66 \pm .79$ & $38.70 \pm .33$ & $35.57 \pm 1.00$ & $39.86 \pm .38$ & 50 \\
\hline Vitamin B12, mg & $0.38 \pm 0.03$ & $0.36 \pm 0.08$ & $0.87 \pm 0.09$ & $0.90 \pm 0.09$ & 0.3 \\
\hline Folate & $229.51 \pm 122.93$ & $135.33 \pm 78.80$ & $216.43 \pm 96.48$ & $153.30 \pm 68.22$ & 160 \\
\hline Cholesterol, mg & $254.92 \pm 161.83$ & $243.77 \pm 138.63$ & $191.78 \pm 172.21$ & $258.48 \pm 181.51$ & 300 \\
\hline
\end{tabular}

$\mathrm{a}=$ animal, $\mathrm{p}=$ plant 
preferences of their student rather than in conformity with dietary recommendations. A report by the Public Opinion Research Center (Zwyczaje, 2006) demonstrates that nearly 60\% of respondents share the opinion that it is important that a child receives its preferable food items and likes the meal.

In both rural and urban areas (boys and girls) none of the diets were deficient in terms of vitamins B2 and B6. Deficiencies of other vitamins affected a very small number of students. In this context, it should be reconsidered whether healthy student should receive so commonly applied supplements of vitamins and fish-liver oil, the latter containingbesides unsaturated fatty acids-considerable amounts of vitamin A.

In conclusion, intake of a diet sufficient to meet or exceed the needs of the individual will keep the composition and function of the otherwise healthy individuals within the normal range. In general, it is of the almost important to know much about the nutritional status evaluation of Egyptian students, preadolescents/ adolescents since in future will be working people in all areas. Results of the present study recommended that total energy intake should be reduced and exercise should be encouraged for preparatory and secondary schools on Egypt science weights were higher than recommended by RDA. Much care should be paid to raise the educational level of the student's parents. Such educational rising will help in enhancing the nutritional culture, behavior, habits of their adolescent boys and girls. The food pattern/ habits of students were found to be faulty such as low vegetables intake, frequent snaking and higher frequency of soft drinks. In this direction, nutritional education programs should be directed to student's parents, specially the mother, who is principally responsible for home meals.

\section{Recommendations}

Those involved in obesity prevention may use these findings to implement school-based food programs and nutritional health education messages with incorporation of skills for proper food choices.
Emphasizing the importance of breakfast, the hazards of frequent eating out and the importance of certain food items in prevention of obesity should be included in any health educational plan.

\section{REFERENCES}

Bibiloni, M., A. Pons and J.A. Tur (2013). Prevalence of overweight and obesity in adolescents: a systematic review. ISRN Obes, 392747.

CDC (2014). Childhood obesity factsAdolescents school health. Available at http://www. cdc.gov/ healthyyouth/ obesity/ facts.htm.

Cesani. M.F, M. Garraza, M.L. Sanchi, A.L. Luis, M.F. Torres, F.A. Quintero and E.E. Oyhenart (2013). A comparative study on nutritional status and body composition of urban and rural school children from brandsen district (Argentina). PLoS ONE, 8 (1): e52792.

Charzewska, J. and H. Weker (2006). Nationwide research on calcium and vitamin $\mathrm{D}$ content in diets of four-year old student. Pediat. W spół. Gastroenterolog. Hepat. Żyw. Dziecka, 8 (2): 107- -109

Ciborowska, H. and A. Rudnicka (2007). Dietetics. Nutrition of the Healthy and Diseased Person. Wyd. Lek. PZWL Warszawa.

Danasekaran, R. and K. Ranganathan (2019). Prevalence of overweight and obesity among rural adolescent school students in Kanchipuram district, Tamil Nadu. Int. J. Community Med. Public Health, 6 (1): 173176.

Dominick, S. and R. Derrick (2001). Theory and Problems of Statistics and Econometrics, $2^{\text {nd }}$ Ed. New York, USA, 202-220.

El-Zanaty, F. and A. Way (2009). Egypt demographic and health survey 2008. Cairo, Egypt: Ministry of Health, El-Zanaty and Associates, and Macro Int.

Ezeama, N.N., B.O.U. Adogu, C.C. Ibeh and E.D. Adinma (2015). Comparative analysis of the nutritional status of under-five children and their mothers in rural and urban areas of 
anambra state, Nigeria. Europ. J. Nutr. Food Safety, 5 (3): 190-201.

Food Composition Tables for Egypt - Nutrition Institute, ARE- 1996* 115 pp (English

Friedrich, M. and M. Rukojć (2001). Assessment of vegetarian and traditional diets and the nutritional status of student aged 1-3. Żywność 28 (3 supl.): 42-52.

Genena, D.M. and A.A. Salama (2017). Obesity and eating habits among university students in Alexandria, Egypt: A cross sectional study. World J. Nutr. and Health, 5 (3): 6268.

Gronowska-Senger, A. (2007). Nutrition, life style and health of the Poles. Żyw. Człow. Metab., 34 (1/2): 12-21.

Kleeman, C.R., J. Bohannan, D. Bernstein, S. Ling and M.H. Maxwell (1964). Effect of variations in sodium intake on calcium excretion in normal humans. Proc. Soc. Exp. Biol. Med., 115: 29-32.

Kolarzyk, E., A. Janik and J. Kwiatkowski (2008). Nutritional habits of pre-school student. Probl. Hig. Epidemiol., 89 (4): $527-$ 532 .

Kozłowska-Wojciechowska, M. and M. Makarewicz-Wujec (2005). Nutritional behavior of pre-school student. Rocz. PZH, 56 (2): 165-169.

Leszczyńska, T., E. Sikora, K. Kręcina and K. Pysz (2007). Meals served in nursery schools and their share in meeting the recommended daily demand for energy and nutrients exemplified by one selected canteen. Żywn. Nauka Techn. Jakość, 55 (6): 327-334.

Nanda, S. (2000). Assessment of an improved module of national adolescent girls scheme and evaluation of ongoing scheme. Ph.D. Dissertation, Chandigarh: Punjab Univ.

Nordin, B.E.C. and K.J. Policy (1987). Metabolic consequences of the menopause. A cross-sectional, longitudinal and intervention study on 557 normal postmenopausal women. Calcif. Tiss. Int., 41: $1-60$.
Nutrition (2004). Vitamin and mineral status: effects on physical performance. Jul-Aug., 20 (7-8): 632-44.

Ołtarzewski, M., L. Szponar and E. Rychlik. (2003). Calcium consumption among student and teenagers in Poland. Żyw. Człow. Metab., 30 (1/2): 278-283.

Pietsch (2009). Growing healthy minds and bodies, a look at nutrition innovation in schools. Nutritional file for health educators. Page:1-8.Available at http://www. moreaboutmilk. com/media/nutrition_file_newsletters/aug200 9nffhefinal.pdf.

Raj, M. and R.K. Kumar (2010). Obesity in student and adolescents. Indian J. Med. Res., $132: 598-607$.

Sadowsk, J., M. Radziszewska and A. Krzymuska (2010). Evaluation of nutrition manner and nutritional status of pre-school student. Acta Sci. Pol., Technol. Aliment., 9 (1): 105-115.

Shaikh, M.K., N. Kamble, D. Bhawnani, S. Bele and S.R. Rao (2016). Assessment of nutritional status among school children of Karimnagar, Telangana, India. Int. J. Res. Med. Sci., 4 (10): 4611-4617.

Sochacka-Tatara, E., R. Jacek, A. Sowa and A. Musiał (2008). Assessment of preschool student's diet. Probl. Hig. Epidemiol., 89 (3): 389-394.

Szczepaniak, B., D. Górecka and A. JędrusekGolińska (2002). Nutritional preferences among student at pre-school age. Acta Sci. Pol., Technol. Aliment., 1: 101-107.

Tawfik, S.E., H.S. Ez-Elarab, W.A. Fahmy and F.A. Meky (2015). Evaluation of nutrition education program among Egyptian adolescents school student (11-14 years old). Egypt. J. Community Med., 33 (4): 67-79.

Walter, T. (1994). Effect of iron-deficiency anemia on cognitive skills in infancy and childhood. Baill. Clin. Haematol., 7 : 815-827.

Weatherholtz, W.M., T.C. Campbell and R. Webb (1969). Effect of dietary protein levels on the toxicity and metabolism of heptachlor. J. Nutr., 98: 90-96. 
WHO (1998). WHO information series on school health. Document 4. Healthy nutrition: An essential element of a health promotion. Geneva: WHO. Available at http:// www. who.int/hpr.

WHO (1999). World Health Organization International Society of Hypertension, 1999. Procedure in the arterial hypertension. Current (1999) guidelines. Med. Prakt., 5 (9): 15-63 .

WHO (2004). Fight childhood obesity to help prevent diabetes, say WHO and IDF Available at http://www.who.int/ mediacentre/ news/ releases/2004/pr81/en/

WHO (2018). World Health Organisation. Factsheet: Obesity and overweight. Available at: http://www.who.int/ en/news-room/factsheets/detail/obesity-and-overweight Accessed on 20 June 2108.

Zwyczaje (2006). Nutritional manner of Poles. Results of public opinion poll]. Centrum Badania Opinii Społecznej Warszawa.

دراسة على النمط الغذائي ومدى انتشار زيادة الوزن و السمنة بين طلاب المدارس بمدينة الزقازيق

إهداء سامي أبو المعاطي ـ داليا أحمد زكى ـ حنان سعيد توفيق ـ أحمد علاء الدين النشوى

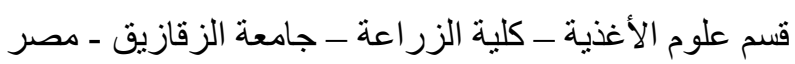

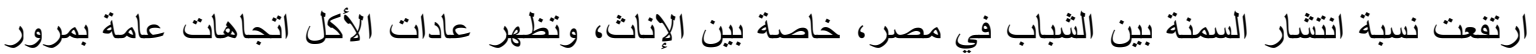

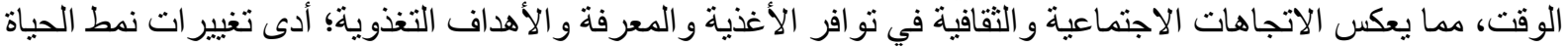

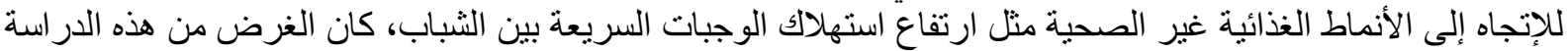

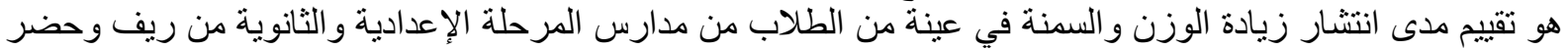

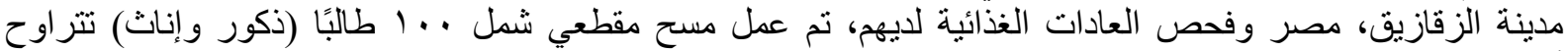

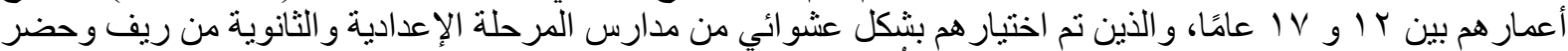

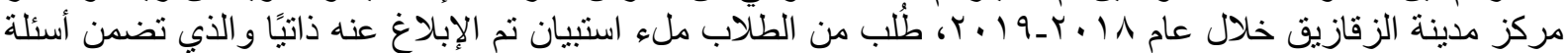

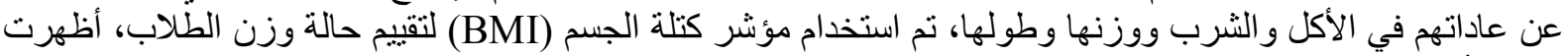

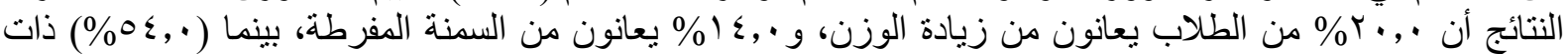

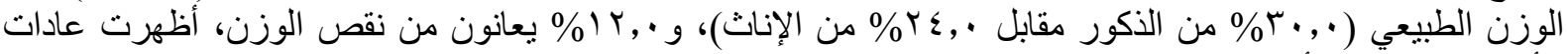

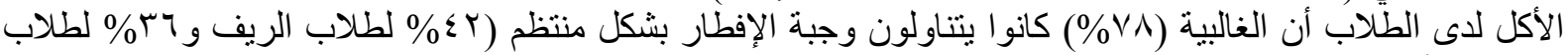

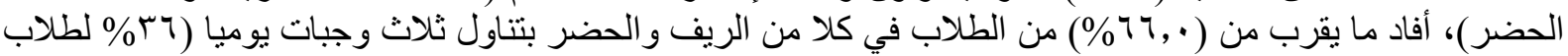

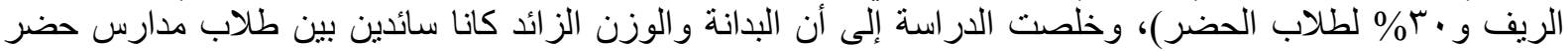

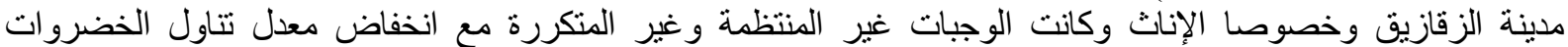
المنخفضة والوجبات الخفيفة المنكررة الأكثر شيوعًا في عادات الكات الأكل غير الصحية للمشاركين: من حيث التئ أنماط الأكل، لوحظت فروق ذات دلالة إحصائية بين الجنسين فيما ينعلق بتناول والئ وجات خفيفة منكررة من قبل الذكور في عينة الدر اسة. 